\title{
EASTERN BOUNDARY CIRCULATION AND HYDROGRAPHY OFF ANGOLA Building Angolan Oceanographic Capacities
}

\author{
P. Tchipalanga, M. Dengler, P. Brandt, R. Kopte, M. Macuéria, \\ P. Coelho, M. Ostrowski, and N. S. Keenlyside
}

The seasonal circulation and interannual hydrographic variability off the coast of Angola is revealed by biannual research cruise data (1995-2017) from the Nansen Programme.

\begin{abstract}
A ngola is located at the Atlantic coast in southwestern Africa between $5^{\circ}$ and $17^{\circ} 20^{\prime} \mathrm{S}$, with borders to the Democratic Republic of Congo in the north and to Namibia in the south. Its coastline stretches over a distance of $1,600 \mathrm{~km}$. The Angolan territorial waters support a highly productive ecosystem. Seasonal upwelling occurs in large parts of its coastal zone during austral winter (Fig. 1). Coupled with a dense coastal population, this marine ecosystem plays a key socioeconomic role in the country's
\end{abstract}

development. Currently, the fishing sector is third in importance to the national economy after the oil and mining industries and supplies about $25 \%$ of the total animal protein intake of the Angolan population (FAO 2011). However, fish resources are found to be affected by climate variability and changes of the eastern boundary upwelling ecosystems (e.g., Gammelsrød et al. 1998; Parrish et al. 2000; Lehodey et al. 2006; Gruber 2011). There is urgent need to understand these impacts to help sustainable
AFFILIATIONS: TChIPALANGA-Departamento do Ambiente e Ecossistemas Aquáticos, Instituto Nacional de Investigação Pesqueira, Moçâmedes, Angola; Dengler AND KoPTE—Physical Oceanography, Ocean Circulation and Climate Dynamics, GEOMAR Helmholtz Centre for Ocean Research, Kiel, Germany; BRANDTPhysical Oceanography, Ocean Circulation and Climate Dynamics, GEOMAR Helmholtz Centre for Ocean Research, and Mathematisch-Naturwissenschaftliche Fakultät, Christian-Albrechts-Universität zu Kiel, Kiel, Germany; MaCUÉRIA AND CoelHo-Instituto Nacional de Investigação Pesqueira, Luanda, Angola; OstrowsKIOceanography and Climate, Institute of Marine Research, Bergen,
Norway; KeENLYSIDE-Geophysical Institute, Bjerknes Centre for Climate Research, University of Bergen, Bergen, Norway CORRESPONDING AUTHOR: Marcus Dengler, mdengler@geomar.de

The abstract for this article can be found in this issue, following the table of contents. DOI:10.1175/BAMS-D-17-0197.I

In final form I February 2018 (C)2018 American Meteorological Society

(c) (i) This article is licensed under a Creative Commons Attribution 4.0 license. 

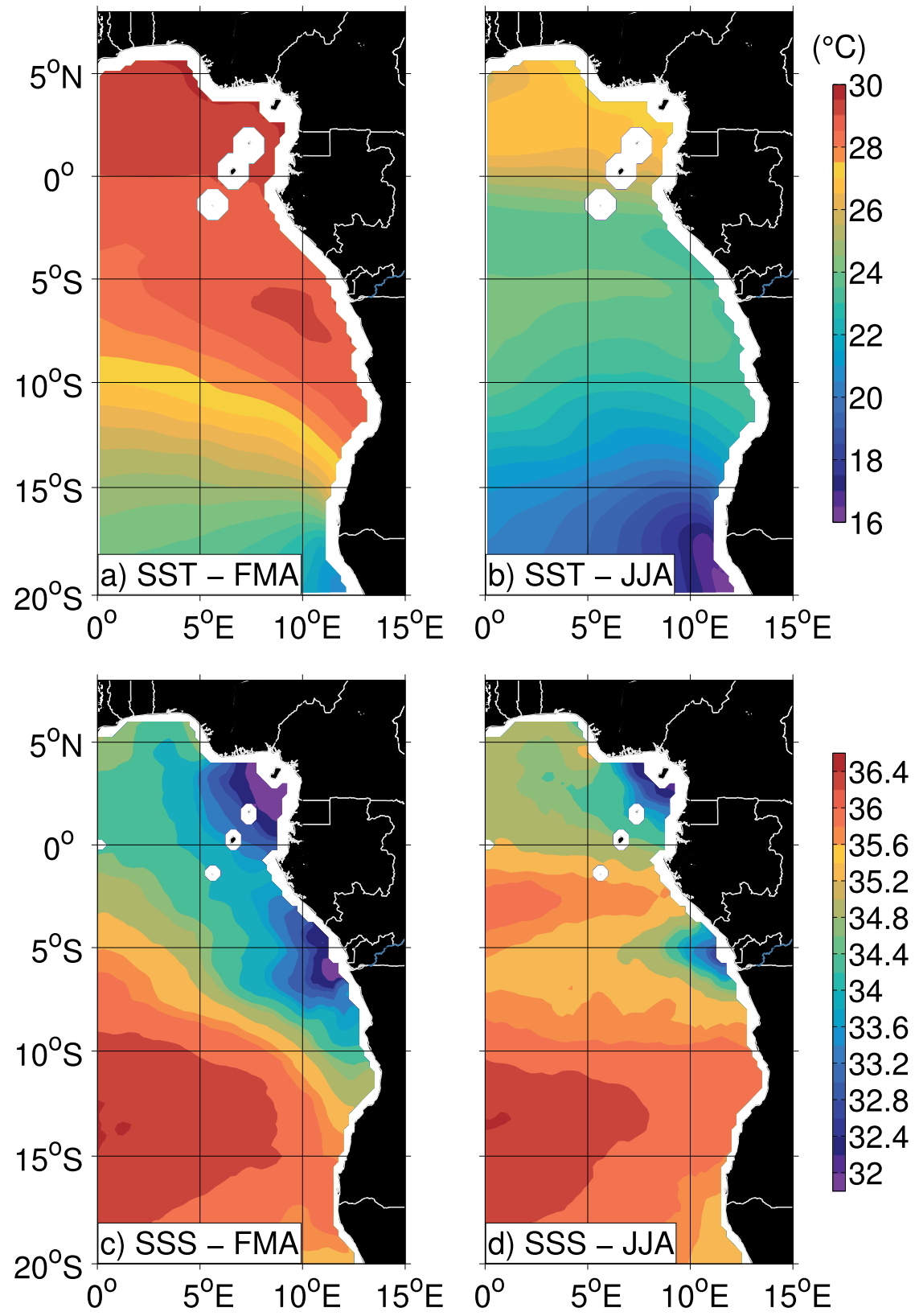

FIG. I. Average sea surface temperature (SST) and sea surface salinity (SSS) in (a),(c) Feb-Apr and (b),(d) Jun-Aug determined from microwave fusion Optimum Interpolation (OI) SST (www.remss.com) and Soil Moisture Ocean Salinity level 3, version 2 (www.catds.fr), satellite data, respectively.

management of the marine resources and to assist Angola in meeting its sustainable management goals.

Below the productive upper ocean, thermocline waters are depleted in oxygen and form one of the most pronounced oxygen minimum zones (OMZs) in the global ocean. Recent observations suggest a decline in oxygen content of the oceans, particularly in the southeastern Atlantic, and an expansion of OMZs, modulated by the interannual, decadal, and multidecadal variability of our climate system (Stramma et al. 2008; Monteiro et al. 2011; Schmidtko et al. 2017). The ocean currents at the continental margin represent a typical tropical eastern boundary circulation system dominated by the poleward-flowing Angola Current. Predominately during austral summer, the Angola Current is thought to transport warm and saline, low-oxygen South Atlantic Central Water (SACW) southward into the coastal upwelling region, possibly resulting in hypoxic to anoxic conditions on the shelf (Mohrholz et al. 2008; Monteiro et al. 2008; Rouault 2012). In turn, the Angola Current is thought to be supplied by the eastward currents in the equatorial region (Peterson and Stramma 1991; Wacongne and Piton 1992; Rouault et al. 2007).

Historically (see sidebar for a detailed description of the history of physical oceanography in Angola), knowledge of the velocity structure and transport of the Angola Current at the coast had been gained exclusively from few synoptic hydrographic data (Moroshkin et al. 1970; Dias 1983a,b; Mercier et al. 2003). These earlier studies found geostrophic poleward flow between the surface and 300-400-m depth having velocities between 30 and $50 \mathrm{~cm} \mathrm{~s}^{-1}$. Transport estimates of the Angola Current determined by Dias (1983a) were 1.2 and $3.7 \mathrm{~Sv}$ $\left(1 \mathrm{~Sv} \equiv 10^{6} \mathrm{~m}^{3} \mathrm{~s}^{-1}\right)$ from data collected in September 1970 and July 1971, respectively. However, Mercier et al. (2003), applying an inverse model to hydrographic sections, reported an Angola Current transport of $11 \mathrm{~Sv}$ in January-March 1995 corresponding to the peak phase of the 1995 Benguela Niño. During a survey in April 1999, a secondary, offshore branch of southward 
The German R/V Meteor expedition in 1925-27 might be considered as the starting point of physical oceanography studies off Angola. This survey included two trans-Atlantic transects with an inserted port call in Moçâmedes in southern Angola. The observational program included hydrographic measurements, providing a general picture of the tropical and South Atlantic water mass and oxygen distribution (Wattenberg 1938; Wüst 1935). The USSR's R/V Akademik Kurchatov carried out a first detailed hydrographic survey off Angola and northern Namibia between April and June 1968. The obtained data were used for a first description of the eastern boundary circulation (Moroshkin et al. 1970). At about the same time, the Portugal Navy and the Mission of Bio-Oceanological Studies of Angolan Fisheries (MEBPA) was established; it later became the INIP. INIP responsibilities included acquisition of oceanographic data at fixed stations, along monitoring lines, and during coastal surveys. Two research vessels, R/V Goa and R/V Sardinella, were employed. Starting in 1967, a transect at about $12^{\circ} \mathrm{S}$ across the continental slope and shelf was taken 4-6 times per year, yielding a first estimate of seasonal variability of the boundary circulation (Dias 1983a). A systematic study covering the shelf of southern Angola started in 1968 with three cruises of R/V Goa per year. Daily data acquisition was performed at the Lobito time series station $\left(12^{\circ} 19^{\prime} \mathrm{S}, 13^{\circ} 35^{\prime} \mathrm{E}\right)$ at about $40-\mathrm{m}$ water depth. These measurements, including several physical and biogeochemical parameters, started in 1968, stopped in 1975, and were restarted in 1978. They are running to this day, although showing many gaps and a general reduction in the parameter range compared to the early measurements. Early data were used to demonstrate the seasonal march of temperature, indicating the presence of primary and secondary upwelling and downwelling seasons off Angola (Berrit and Dias 1977). Similar time series stations were established at $13^{\circ} 45^{\prime} \mathrm{S}$ (Santa Marta) and $15^{\circ} \mathrm{S}$ (Moçâmedes), both discontinued in 1975 .

The turmoil of the war for independence in 1975 saw the most difficult period in the history of the Angolan oceanography. Most of the infrastructure, instruments, and equipment were lost and much of the collected literature, reports, and data were dispersed. In the early 1980s, the Angolan Ministry of Fishery signed an agreement with the Swedish International Cooperation Agency to, among others, rebuild the R/V Goa. Sporadic research surveys were carried out with the rebuilt vesse or with Cuban and USSR research vessels aiming to monitor the main fishing resources.

The arrival of the Nansen Programme to Angola in the mid-1980s marked the beginning of a new era in the monitoring of the Angolan coastal ocean and its living resources. The surveys with the R/V Dr. Fridtjof Nansen were first conducted in 1985. Since 1995, these surveys have been carried out twice a year, covering the entire extent of the Angolan continental shelf.

The regional cooperation among Angola, Namibia, and South Africa was improved through the programs Benguela Environment Fisheries Interaction and Training (BENEFIT, 1999-2009) and Benguela Current Large Marine Ecosystem (BCLME, 2002-08; now Benguela Current Commission). These programs particularly addressed climate variability associated with extreme environmental events, including the Benguela Niños. Under the umbrella of BENEFIT, several research cruises with German R/Vs Poseidon, Meteor, Petr Kottsov, and Alexander von Humboldt and the South African R/V Africana were carried out. A new monitoring program was also established along a section off Moçâmedes, with II surveys completed until now and still ongoing. Different bilateral agreements allowed frequent visits by research vessels from different countries, mostly from Germany, Spain, Portugal, Great Britain, Russia, and Cuba.

More recently, the NansClim project (2009-14) was implemented between Norway, Angola, Namibia, and South Africa (Jarre et al. 2015). By using data collected through the Nansen Programme and other relevant regional data, the project aimed at studying ocean and climate variability and corresponding changes in marine biodiversity. The cooperation between Germany, Angola, Namibia, and South Africa was fostered through the Geochemistry and Ecology of the Namibian Upwelling System (GENUS, 2009-15) and Science Partnerships for the Assessment of Complex Earth System Processes (SPACES, 2012-18) programs, which included additional cruises with R/Vs Maria S. Merian and Meteor as well as first direct velocity observations from moorings in the Angola Current (Kopte et al. 2017). The latter was performed also in cooperation with the EU-PREFACE (2013-17) project, having 28 partners across 18 countries in Europe and Africa. EUPREFACE has enhanced the Angolan observing system by funding additional cruises, autonomous measurement programs, and equipment for an oceanmeteorology buoy in the PIRATA network (Bourlès et al. 2008) at $6^{\circ} \mathrm{S}$, $8^{\circ} \mathrm{E}$ (PIRATA Southeast extension). subsurface flow was identified in shipboard velocity data separated from the coastal branch (Mohrholz et al. 2001). Both pathways were characterized by poleward velocities of about $40 \mathrm{~cm} \mathrm{~s}^{-1}$ below the surface.

However, recent direct multiyear velocity observations of the Angola Current by acoustic Doppler current profilers (ADCPs) attached to two moorings at $11^{\circ} \mathrm{S}$ revealed alternating poleward and equatorward flow having periods of a few months with superimposed high-frequency velocity pulses (Kopte et al. 2017). The strength of the variable flow is in agreement with previous synoptic measurements, but the mean poleward flow is weak. Maximum average velocities were only between 5 and $8 \mathrm{~cm} \mathrm{~s}^{-1}$, and the 
mean poleward flow extended from the surface to 200-m depth.

The variability of the Angola Current appears to be largely controlled by the passage of coastally trapped waves (CTWs; Ostrowski et al. 2009; Rouault 2012; Bachèlery et al. 2016; Kopte et al. 2017). These waves communicate equatorial oceanic variability along the continental margin of Angola to the northern Benguela upwelling region. From the analysis of satellite data, four CTW events per year were described to propagate along the southwestern coast of Africa as far south as $20^{\circ} \mathrm{S}$ (Fig. 2; Schouten et al. 2005; Lazar et al. 2006; Ostrowski 2007; Ostrowski et al. 2009; Kopte et al. 2017). The first downwelling (high sea level) equatorial Kelvin wave and subsequent CTW arrive at the Angolan coast in March, followed by an upwelling (low sea level) CTW in June-July. The second cycle begins with downwelling in October and ends with a weak upwelling signal in DecemberJanuary. In addition, altimetry and regional ocean

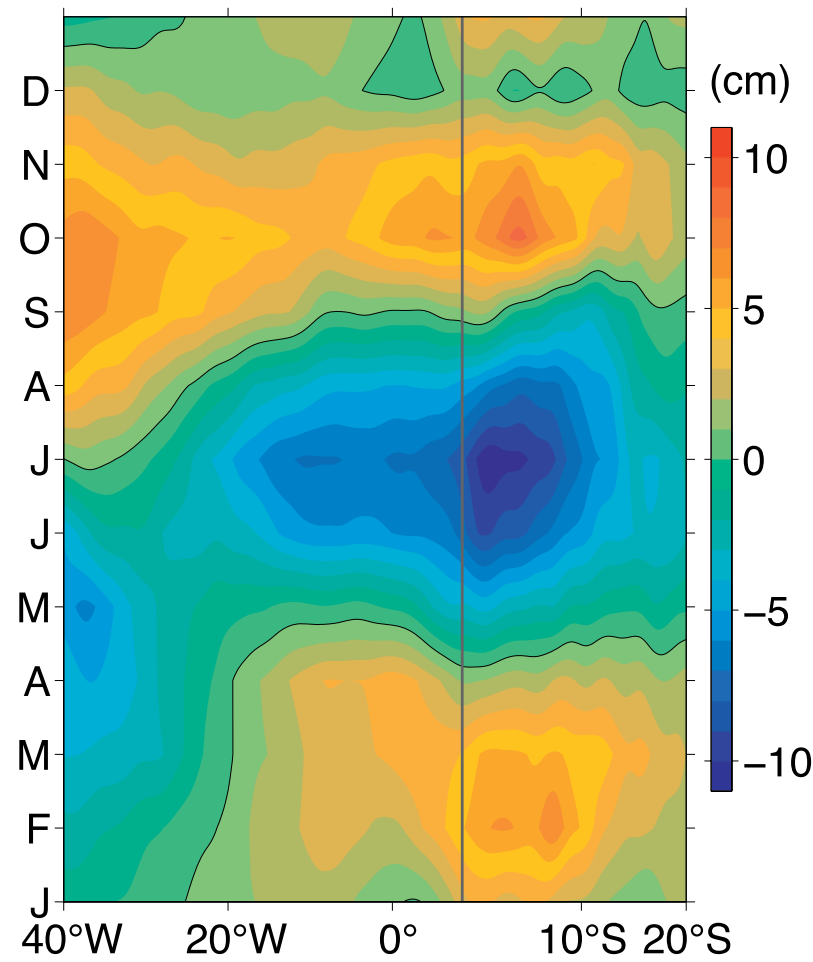

FIG. 2. Hovmöller diagram of the mean annual cycle of sea level anomaly showing the propagation of upwelling (Jun, Dec) and downwelling (Feb, Oct) Kelvin waves from west to east along the equator. The equatorial Kelvin wave signal is then carried southward along the eastern boundary by coastally trapped waves. The vertical black line separates the region of eastward propagation along the equator to the left and the region of southward propagation along the coast to the right. simulations revealed equatorial forced CTWs having interannual time scales (13-20 months; Bachèlery et al. 2016). Along the Angolan and Namibian continental margin, CTWs contribute to triggering sea surface temperature (SST) anomalies, which impact atmospheric circulation and rainfall (Shannon et al. 1986; Rouault et al. 2003; Imbol Koungue et al. 2017; Rouault et al. 2018). CTWs may also modulate biogeochemical conditions in the coastal upwelling ecosystems and directly impact fisheries by displacing fish eggs and larvae latitudinally along the continental margin (e.g., Ostrowski 2007).

Besides equatorial wave forcing, theoretical, modeling, and observational studies have shown that local wind forcing plays an important role in setting the structure and driving the variability of the eastern boundary circulation in upwelling regions, including the Benguela upwelling (McCreary and Chao 1985; Marchesiello et al. 2003; Fennel et al. 2012; Junker et al. 2015; Small et al. 2015). In particular, the southern Angola region and the Benguela upwelling to the south are impacted by strong southerly surface winds associated with the Benguela atmospheric low-level coastal jet (e.g., Nicholson 2010; Patricola and Chang 2017). Before it veers offshore, the atmospheric lowlevel coastal jet has a quasi-permanent northern maximum located at about $17.5^{\circ} \mathrm{S}$ that coincides with the Cunene upwelling cell (Lutjeharms and Meeuwis 1987; Patricola and Chang 2017). This maximum is related to a maximum in negative wind stress curl between $15^{\circ}$ and $20^{\circ} \mathrm{S}$, which is considered to be the main driving mechanism for poleward flow along the eastern boundaries (e.g., McCreary and Chao 1985; Marchesiello et al. 2003; Fennel et al. 2012; Junker et al. 2015).

Between $15^{\circ}$ and $18^{\circ} \mathrm{S}$, the Angola-Benguela Front represents a sharp but variable thermal front (Fig. 1), separating tropical, oligotrophic waters to the north from cold, nutrient-rich waters to the south (Shannon et al. 1987; Lass et al. 2000). Across-front temperature differences range from $5^{\circ}$ to $8^{\circ} \mathrm{C}$. The front fluctuates in position and strength on time scales from intraseasonal (Kostianoy and Lutjeharms 1999; Mohrholz et al. 2001; Goubanova et al. 2013; Diakhaté et al. 2016) to annual (Meeuwis and Lutjeharms 1990) to interannual. Interannual variability in the frontal region is often associated with severe warm and cold events during austral summer termed Benguela Niños and Benguela Niñas, respectively (Shannon et al. 1986; Florenchie et al. 2004; Rouault et al. 2018). Benguela Niños are marked by a poleward intrusion of warm equatorial water and reduced upwelling (Fig. 3), while SST anomalies of up to $5^{\circ} \mathrm{C}$ off 
the coast of Angola and Namibia are observed (e.g., Junker et al. 2017). Benguela Niños/Niñas are known to have a strong impact on precipitation variability over adjacent countries (e.g., Rouault et al. 2003) as well as on the marine ecosystem and local fisheries (Gammelsrød et al. 1998; Boyer and Hampton 2001). There is a tremendous social and economic interest within the southern African community in the prediction of these climate anomalies. However, the presence of an exceptionally large bias in SST in the southeast Atlantic in state-of-the-art climate models likely limits the predictability of interannual variability and introduces uncertainties in the response to climate change (Wahl et al. 2011; Toniazzo and Woolnough 2014; Xu et al. 2014; Zuidema et al. 2016; Koseki et al. 2018).

In the past, very little data from field surveys along the Angolan continental margin have been analyzed and published. Because of the lack of observations, understanding of the boundary circulation and its variability is hardly developed, and the lack of data and process understanding prohibits satisfactory evaluation of model simulations and reanalysis products. However, as described below, it is not that there were no field campaigns in Angolan territorial waters. One purpose of the article is to bring these to light.

THE NANSEN PROGRAMME. The idea of committing a research vessel to assist newly independent countries in assessing their fish resources dates back to the 1960s in Norway. It was substantiated a decade later when the government of Norway and the Food and Agriculture Organization of the United Nations (FAO) established the Nansen Programme. The first research vessel, named Dr. Fridtjof Nansen, was launched in 1974. Since then, she and her two successor vessels with the same name (launched in 1994 and 2017, respectively) continue to this day to support fisheries and, more recently, ecosystem research and monitoring in developing countries around Africa and elsewhere (Bianchi et al. 2016).

In the Angolan territorial waters, the fish monitoring surveys by R/V Dr. Fridtjof Nansen have been carried out since 1985 and since 1995 on a regular biannual basis. The swept area trawl and acoustic fish census surveys dominated the survey designs and data collection (Sætelsdal et al. 1999). Notwithstanding, hydrographic and velocity data from a shipboard ADCP were also acquired during the cruises.

The biannual cruises were scheduled during austral summer (February-April) and winter (June-August). Between March 1995 and March 2015, a total of 8,818 conductivity-temperature-depth (CTD)

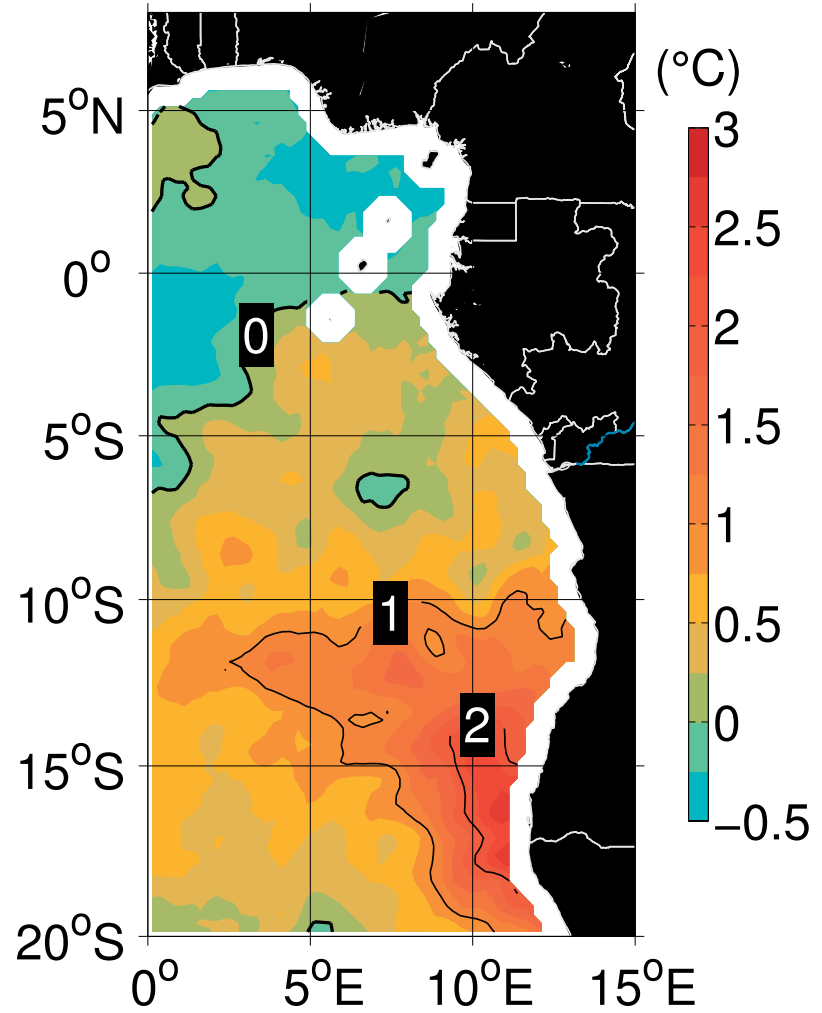

FIG. 3. SST anomaly during the Benguela Niño event in Feb $201 \mathrm{I}$ derived from microwave fusion OISST satellite data. The temperature anomaly was calculated relative to the mean seasonal cycle.

profiles were collected on the shelf and on the continental slope along the entire Angolan coast (Fig. 4). Furthermore, shipboard ADCP measurements with a $150-\mathrm{kHz}$ Ocean Surveyor are available since 2005, and regularly repeated monitoring lines along $6^{\circ}, 9^{\circ}$, $12^{\circ}, 15^{\circ}$, and $17^{\circ} \mathrm{S}$ were established.

By virtue of the Nansen Programme data policies, all collected data have been transferred to and are exclusively owned by the country in which the survey was conducted. As capacities to postprocess and interpret the recorded oceanographic datasets in Angola have not been available in the past, the hydrographic and velocity data remained largely unpublished to date.

\section{ANGOLAN CAPACITY-BUILDING CON-}

TEXT. Developing sustained cooperation between Angolan and European partners is an integral component of many European Union (EU)-funded and national-funded programs focusing on ocean research in the Benguela upwelling region. Enhancing capacities in marine science in the African countries will improve long-term cooperation and is thus pivotal to the success of cooperative projects. Capacity building in fisheries research and management between 
Norway and Angola has been the long-term focus of the Nansen Programme (Bianchi et al. 2016). However, Angola has also recognized the need for development of local expertise in physical oceanography and its impacts on ecosystem and fisheries dynamics. To address this need, capacitybuilding programs have been implemented in the frame of different EU and bilateral projects jointly developed by Angolan, European, and South African partner institutes. The main elements of these programs are 1) training of Angolan scientists at European partner institutions during monthlong visits and during surveys of research vessels; 2) education of scientists, graduate students, and doctoral students during summer schools held in African countries; 3) short courses for students lectured by European scientists at the Instituto Nacional de Investigação Pesqueira (INIP) in Angola; and 4) collaborative studies for scientists and education for graduate students at the Nansen-Tutu Centre in South Africa.

A central objective of the capacity-building program was to scientifically exploit the extensive physical oceanography dataset from the repeat measurements of the Nansen Programme residing in the hands of Angolan scientists. Training of Angolan scientists focused on the calibration and analysis of the datasets at hand. Furthermore, Angolan scientists have maintained fixed oceanographic stations at several locations along the Angolan coast [Luanda, Lobito, and Moçâmedes (named Namibe between 1985 and 2016)]. These time series data have neither been quality controlled nor disseminated. Capacitybuilding efforts thus include quality-control algorithms and data dissemination strategies. Finally, midsized research vessels such as the Angolan R/V Pensador have been used by INIP, but technical skill in instrumental servicing is low. Training of Angolan scientists thus involved education in strengthening technical skills related to oceanographic instrumentation during recently conducted cruises with the R/V Dr. Fridtjof Nansen and R/V Meteor.
Sustained long-term involvement in marine science capacity building by scientists beyond the timeline of recent programs such as the EU's Enhancing Prediction of Tropical Atlantic Climate and Its Impacts (EU-PREFACE), the German Federal Ministry of Education and Research's Southwest African Coastal Upwelling System and Benguela Niños (BMBF-SACUS), and other currently funded projects is urgently required.

\section{EASTERN BOUNDARY CIRCULATION AND HYDROGRAPHY OFF ANGOLA. Up-} per-ocean velocity data acquired with R/V Dr. Fridtjof Nansen's $150-\mathrm{kHz}$ Ocean Surveyor ADCP between 2005 and 2016 for the first time allow a description of the large-scale characteristics of the eastern boundary circulation off Angola. As the cruises have been carried out on a quasi-regular biannual basis, the dataset facilitates the comparison of the mean current structure along the Angolan coast during the main downwelling and upwelling periods in February-April and June-August, respectively (Fig. 5). Please note that the Nansen dataset is restricted to those periods and thus does not cover the full seasonal cycle.

During the main downwelling period in austral summer (Fig. 2), the Angola Current is restricted to the upper $120 \mathrm{~m}$ in the north and gradually deepens to $200-\mathrm{m}$ depth at $17^{\circ} \mathrm{S}$ south. Below the Angola Current, 
a weaker northward return flow is observed. Maximum poleward velocities exceeding $30 \mathrm{~cm} \mathrm{~s}^{-1}$ are found just north of the Angola-Benguela Front at $16^{\circ} \mathrm{S}$, and the flow generally strengthens south of $12^{\circ} \mathrm{S}$. This downstream flow divergence illustrates that the water masses carried poleward cannot solely be supplied from the north. Entrainment of waters from offshore must occur, presumably as part of the Angola Dome circulation, which is further supported by the downstream shoaling of isopycnals (Fig. 5a). During austral winter poleward velocities do not exceed $15 \mathrm{~cm} \mathrm{~s}^{-1}$. However, the poleward flow extends to greater depth during austral winter com-

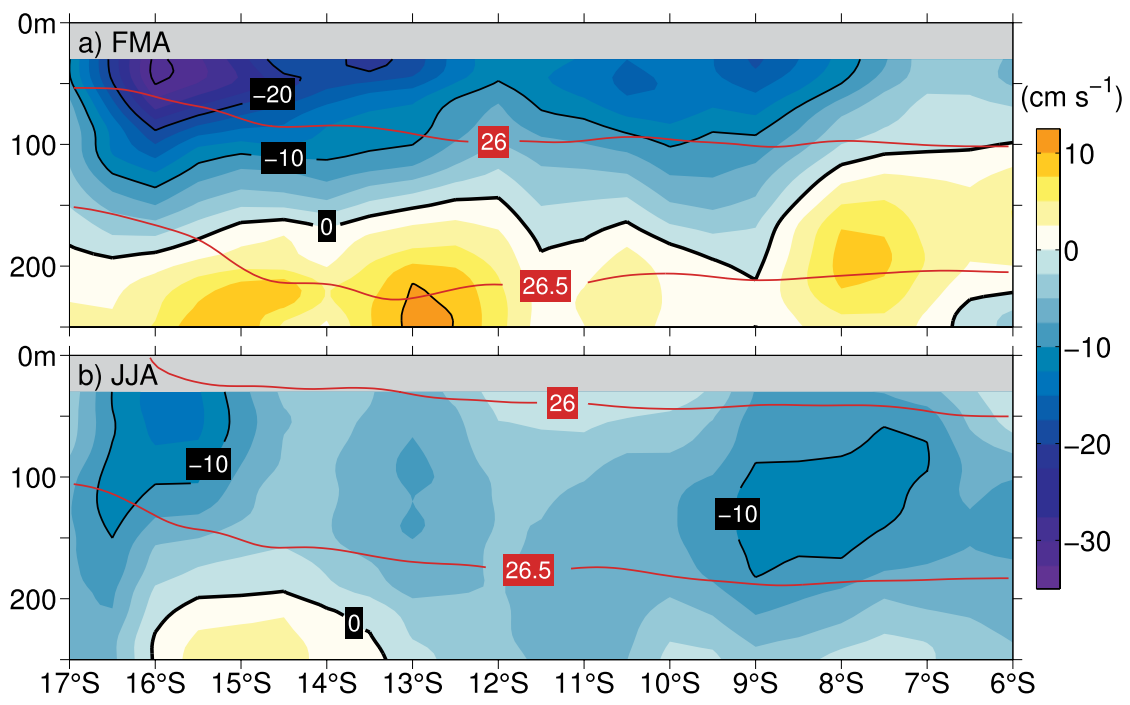

FIG. 5. Average alongshore velocity $\left(\mathrm{cm} \mathrm{s}^{-1}\right)$ during (a) austral summer (FebApr) and (b) austral winter (Jun-Aug). Negative alongshore flow indicates poleward velocities. The depth of the permanent thermocline is indicated by the bounding isopycnals $\sigma_{\theta}=26.0$ and $26.5 \mathrm{~kg} \mathrm{~m}^{-3}$ (red solid lines). Mean alongshore velocity components were calculated by averaging all velocity data acquired in the depth range between 100 and $1,000 \mathrm{~m}$. The local orientation of the shelf break was used to determine the alongshore flow component. Altogether, upper-ocean velocity data from 17 Nansen cruises were used: 9 were conducted during summer and 8 during winter. pared to summer (Fig. 5b).

Elevated velocities within the Angola Current are again found between $15^{\circ}$ and $17^{\circ} \mathrm{S}$.

The seasonal differences in the strength and vertical structure of the current are most likely explained by CTWs (Fig. 2; e.g., Rouault et al. 2007; Ostrowski et al. 2009; Kopte et al. 2017, 2018). The passage of the downwelling CTW in austral summer causes enhanced poleward flow. On the contrary, the upwelling CTW weakens poleward flow during June-August. However, the strengthening of the Angola Current in the south and associated flow divergence is presumably driven by the local near-coastal wind stress curl (Fig. 6). South of $12^{\circ} \mathrm{S}$, the Sverdrup transport, proportional to the wind stress curl, increases and reaches a local maximum between $15^{\circ}$ and $17^{\circ} \mathrm{S}$. This maximum is associated with a wind stress maximum originating from the Benguela atmospheric low-level coastal jet.

Seasonally averaged velocity profiles from a current meter array installed at the continental slope near $11^{\circ} \mathrm{S}$ between July 2013 and October 2015 (Kopte et al. 2017) compare well with the corresponding velocity profiles extracted from the Nansen data at the mooring positions (Fig. 7). The seasonal differences in maximum poleward velocity and the baroclinic structure of the mean vertical velocity profiles are consistently reproduced by the independent dataset.
However, although not statistically significant, there is a tendency for a stronger Angola Current in the shipboard observations representing the period from 2005 to 2016 in comparison to the mean flow observed during the period of moored observations from 2013 to 2015 for the respective seasons. It should be noted that the onshore flow of $1-2 \mathrm{~cm} \mathrm{~s}^{-1}$ suggested by the average velocities from the moorings between 70- and 200-m depth (Fig. 7) supports an entrainment of offshore water masses into the boundary current.

CTD data from the Nansen cruises were used to construct average hydrographic sections for the austral summer and winter seasons. All Nansen CTD profiles collected in water depths deeper than $100 \mathrm{~m}$ but restricted to a coastal band extending to $0.6^{\circ}$ offshore of the $100-\mathrm{m}$ isobath were incorporated into the analysis. Because of the stretched shelf north of $8^{\circ} \mathrm{S}$, the longitude range for averaging was enlarged, extending to $1.5^{\circ}$ offshore of the $100-\mathrm{m}$ isobath for this northernmost region. Between 1995 and 2016, more than 5,700 CTD profiles complied with these specifications. The total number of profiles is distributed nearly equally between summer and winter (Fig. 4b).

During austral summer, temperatures in the nearsurface layer are above $20^{\circ} \mathrm{C}$ along the entire section (Fig. 8a), while a shoaling of isotherms is observed 


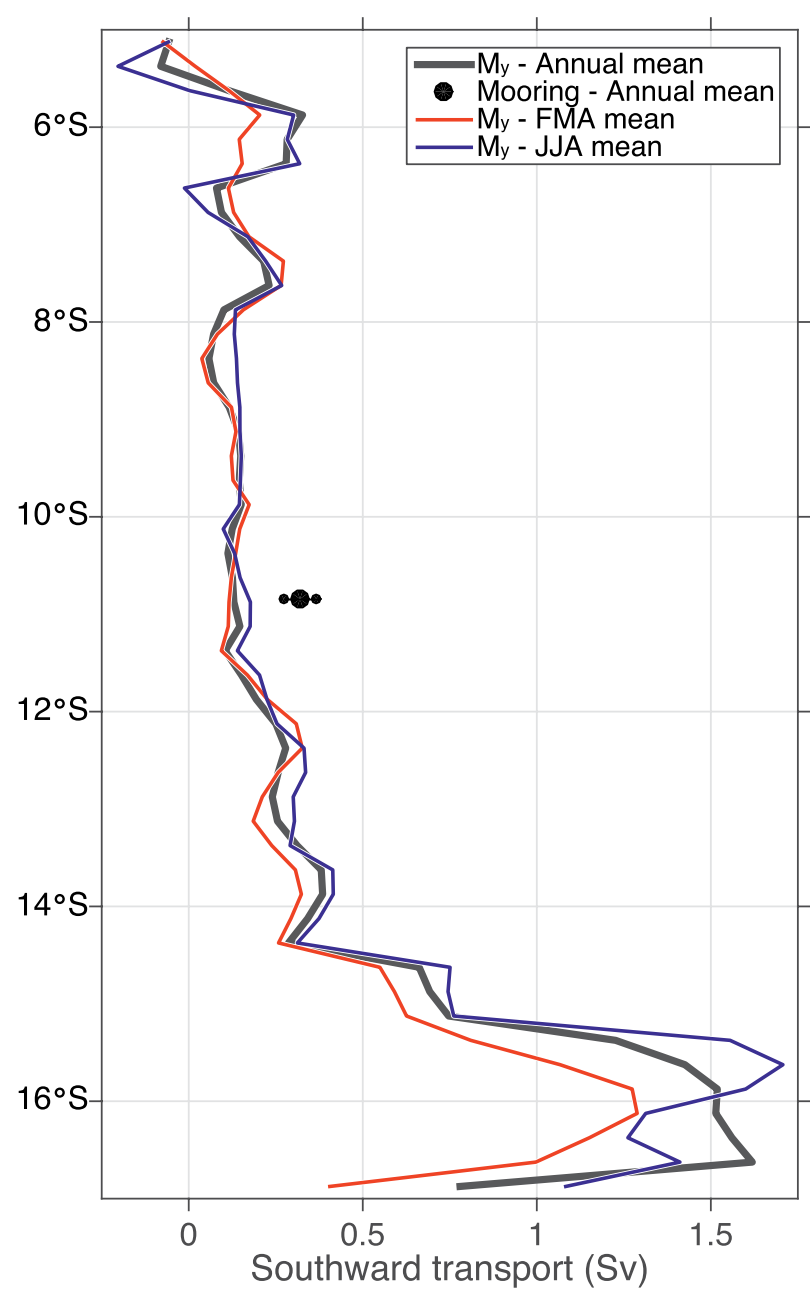

Fig. 6. Southward Sverdrup transport derived from the Scatterometer Climatology of Ocean Winds (SCOW) wind stress curl product (Risien and Chelton 2008) using $M_{y}=\beta^{-1} \operatorname{curl}(\tau)$, where $\beta=\partial f / \partial y$ represents the meridional derivative of the Coriolis parameter $f$ and $\tau$ is the local wind stress vector. The average Angola Current transport determined from the moorings at $1 I^{\circ} \mathrm{S}$ and its uncertainty published in Kopte et al. (20I7) are indicated by the black dots.

during austral winter along with an outcropping of the $20^{\circ} \mathrm{C}$ isotherm at about $12.5^{\circ} \mathrm{S}$ (Fig. 8b). During austral summer, a thin surface layer with temperatures exceeding $25^{\circ} \mathrm{C}$ and salinities below 35 spreads south as far as $13^{\circ} \mathrm{S}$ (Figs. 8a, 9a). This surface layer is completely absent in austral winter (Figs. 8b, 9b). Likewise, the upper thermocline, represented by the density range between $\sigma_{\theta}=26.0 \mathrm{~kg} \mathrm{~m}^{-3}$ and $\sigma_{\theta}=26.5 \mathrm{~kg} \mathrm{~m}^{-3}$, undergoes seasonal variations in depth. The outcropping of the $26.0 \mathrm{~kg} \mathrm{~m}^{-3}$ isopycnal at the southern edge of the section during austral winter (Figs. 8b, 9b) is an indicator for the seasonal march in latitude of the Angola-Benguela frontal zone (Meeuwis and Lutjeharms 1990). Below the
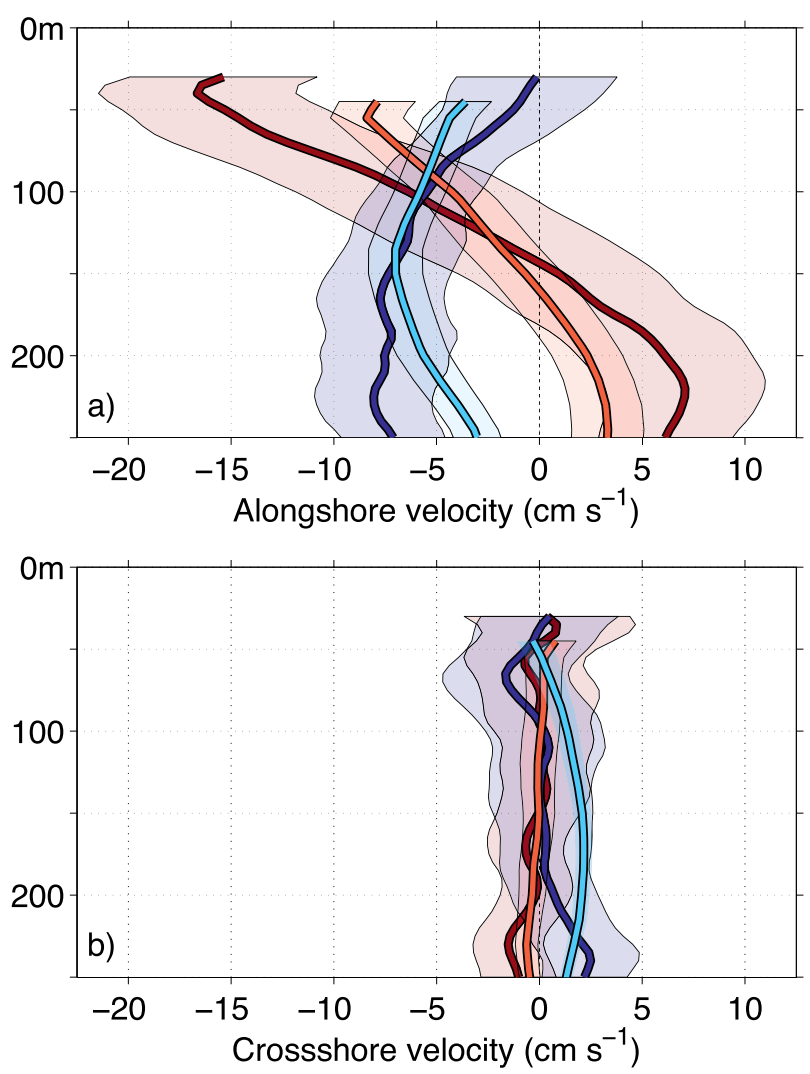

Fig. 7. Mean profiles of (a) alongshore and (b) crossshore velocity near $11^{\circ} \mathrm{S}$ off Angola for austral summer (Feb-Apr) and austral winter (Jun-Aug) derived from vessel-mounted ADCP data (2005-16; dark red and dark blue, respectively) and moored ADCP data (Jul 2013 to Oct 2015; light red and light blue, respectively). Negative velocities indicate poleward/offshore flow. Shadings indicate the corresponding uncertainty of the mean velocities as function of depth. Uncertainties of the vessel-mounted ADCP data were calculated from standard deviation of velocity divided by square root of realizations (i.e., cruises); mooring data uncertainties were determined from standard deviation of velocity divided by the square root of degrees of freedom. The latter were based on correlation analysis.

thermocline, only minor changes in the water mass composition are found between the seasons. The near-constant water mass composition in the central water layer with regard to the seasonal cycle was also noted by Kopte et al. (2017).

Associated with the seasonal changes in temperature and salinity, there is a substantial variability in the stratification represented by the buoyancy frequency in Fig. 10. Near-surface stratification is an important parameter for the supply of nutrients to the euphotic zone by turbulent mixing processes, with increased stratification during austral summer acting to suppress mixing. Moreover, the seasonal changes of upper-ocean stratification also play a crucial role for the amount of 
tidal energy transmitted onto the shelf by internal waves due to tide-topography interaction at the continental slope (e.g., Hall et al. 2013; Lamb 2014). Internal waverelated mixing processes on the continental slope and shelf are thought to represent a critical physical controlling factor for the biological productivity in Angolan waters (Ostrowski et al. 2009).

Exemplary upper-ocean cross-shore sections of alongshore velocity averaged between $10^{\circ}$ and $12^{\circ} \mathrm{S}$ (Fig. 11) show the core of the Angola Current between 50 and $60 \mathrm{~km}$ offshore during both seasons. This distance

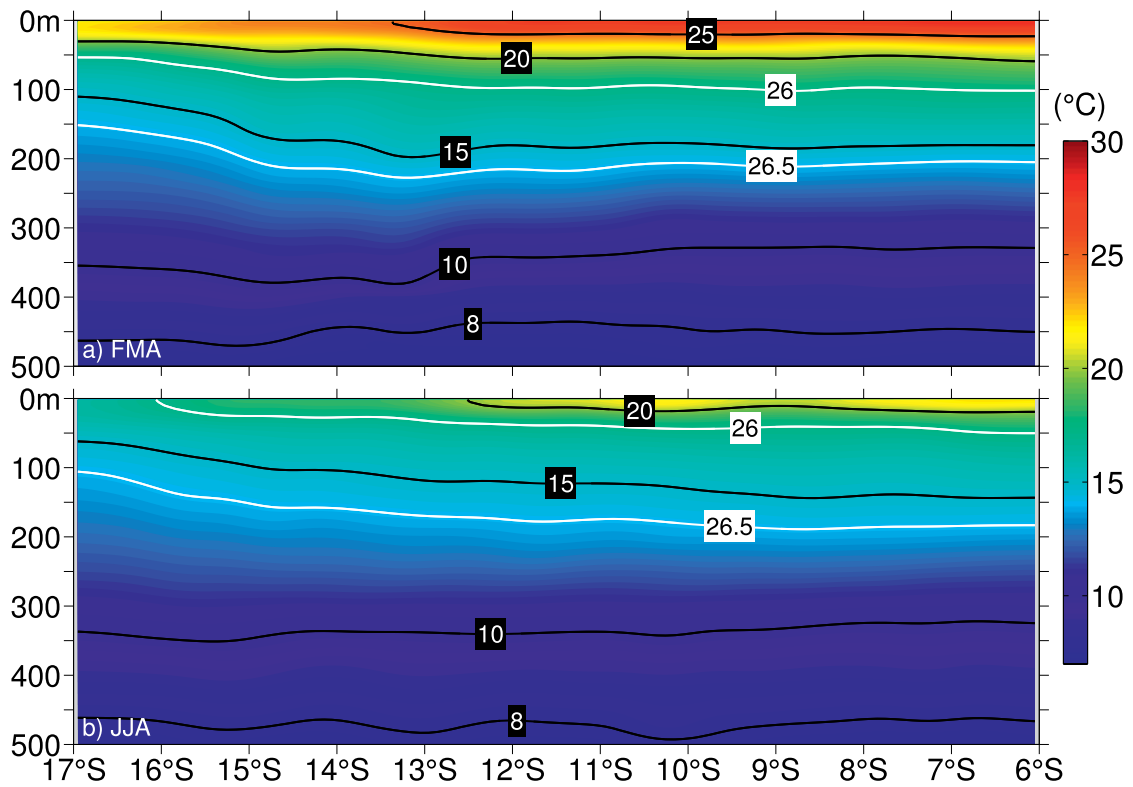

Fig. 8. Latitude-depth distribution of temperature along the continental margin of Angola during (a) austral summer and (b) austral winter. Average isopycnals $\sigma_{\theta}=26.0$ and $26.5 \mathrm{~kg} \mathrm{~m}^{-3}$ are indicated by the white solid lines. roughly corresponds to the $500-\mathrm{m}$ isobath. The flow is stronger and confined to shallower depths during austral summer, while it is weaker but deeper reaching during austral winter (Figs. 11a,b). Temperature and salinity as well as stratification across this section are rather uniformly distributed. The warm, low-salinity surface layer is found throughout the section during austral summer (Figs. 11c,e) but is absent during austral winter (Figs. 11d,f). Near-surface isopycnals show some indication of downwelling and upwelling: during austral summer; these isopycnals bend downward toward the

shore, suggesting downwelling, while during austral winter, the same isopycnals tilt upward as they approach the shore, indicating upwelling.

\section{INTERANNUALVARIABILITY OF HYDROG-}

RAPHY. Local temperature anomalies calculated on isopycnals can be used to analyze the presence of different central water masses in the upper thermocline. The SACW and the fresher but well-oxygenated eastern SACW (ESACW) are the two main central water masses found off the southwest African coast.

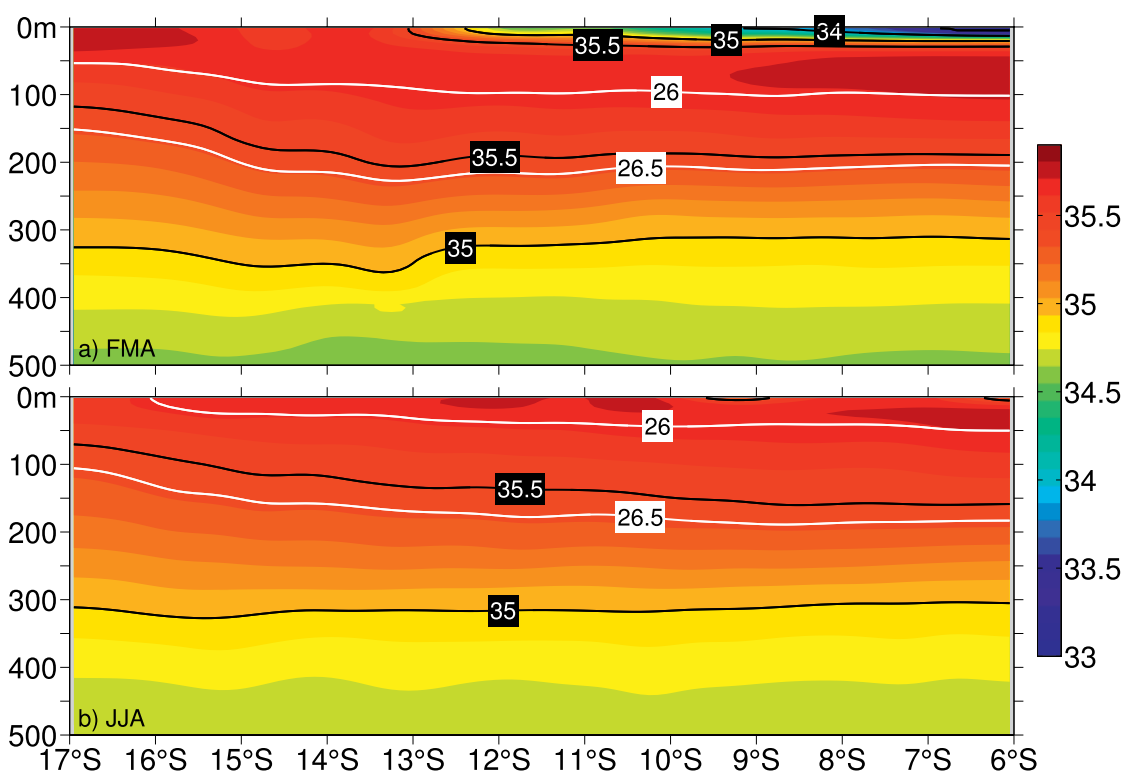

FIG. 9. As in Fig. 8, but for salinity.
SACW is formed in the subtropical convergence of the Brazil-Malvinas confluence zone (Poole and Tomczak 1999). On its way following the South Atlantic subtropical gyre circulation and the equatorial current system toward the Angola Gyre, the properties of SACW are constantly altered. Continuous remineralization of organic matter causes oxygen depletion and nutrient enrichment. Furthermore, weak entrainment of North Atlantic Central Water (NACW) within the equatorial current system modifies the properties of SACW 


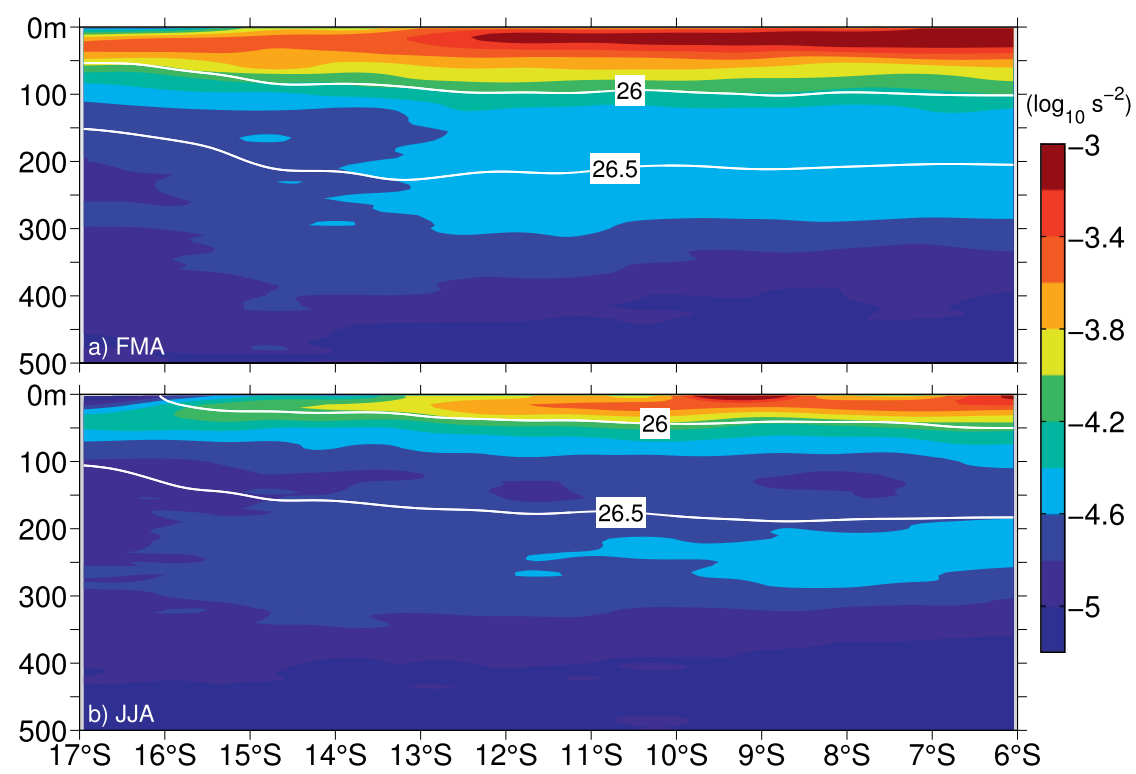

FIG. 10. As in Fig. 8, but for $\log _{10}$ of buoyancy frequency squared $\left(N^{2}\right)$. anomalies of the SST in the Angola-Benguela area $\left(20^{\circ}-\right.$ $10^{\circ} \mathrm{S}, 8^{\circ}-15^{\circ} \mathrm{E}$ ) (Fig. 12a). Often, the observed isopycnal thermocline anomalies precede the respective SST signal. The known Benguela warm events in 2001 and 2011 were associated with warm isopycnal thermocline anomalies. Similarly, the isopycnals were anomalously cold preceding the Benguela Niña event in 1997. Notably, the presence of a subsurface isopycnal warm anomaly present 2 years before the Benguela Niño in 2011 suggests that thermocline isopycnal heat anomalies may (Poole and Tomczak 1999). To account for these en route modifications of SACW, Mohrholz et al. (2008) defined an Angola Gyre subtype of SACW that finally is advected poleward toward the northern Benguela by the Angola Current. ESACW originates in the Cape Basin and represents a mixture of SACW from the subtropical gyre and Indian Central Water that is transferred to the South Atlantic by the Agulhas Current (Mohrholz et al. 2008). The Benguela Current transports ESACW from its source region northward along the southwest African shelf.

The CTD data collected during $63 \mathrm{R} / \mathrm{V}$ Dr. Fridtjof Nansen cruises and three R/V Meteor cruises along the Angolan continental margin from March 1995 to November 2016 exhibit elevated interannual to decadal variability of heat and salt content on isopynals in the upper thermocline (Fig. 12b). Between isopycnal $\sigma_{\theta}=26.0 \mathrm{~kg} \mathrm{~m}^{-3}$ and $\sigma_{\theta}=26.5 \mathrm{~kg} \mathrm{~m}^{-3}$, warm and saline water mass anomalies were found farther to the south between 1999 and 2001 as well as between 2008 and 2013. On the contrary, cold and fresh water mass anomalies, likely associated with enhanced contributions of ESACW, were displaced farther to the north between 1996 and 1998, from 2002 to 2006, and since 2015 . The interannual subsurface temperature anomalies of up to $0.4^{\circ} \mathrm{C}$ might represent an additional forcing of upper-ocean temperature and SST variability otherwise largely explained by the impact of upwelling and downwelling CTWs (Florenchie et al. 2004; Lübbecke et al. 2010; Bachèlery et al. 2016; Imbol Koungue et al. 2017).

The isopycnal warm and cold anomalies in the upper thermocline have indeed some similarities with serve as a preconditioning for the occurrence of Benguela Niños.

A possible explanation of the interannual subsurface variability on isopycnals is anomalous heat advection within the Angola Current. The distribution of water mass anomalies in the thermocline of the eastern tropical Atlantic suggests that the water mass anomalies found during the subsurface warm anomaly off Angola during 2008-10 were transported from the eastern equatorial Atlantic southward along the Angolan coast (Fig. 13a), which might be associated with an anomalously strong Angola Current during this period. Likewise, the subsurface cold anomaly during 2015-16 was associated with colder water masses in the upstream eastern equatorial Atlantic (Fig. 13b).

SUMMARY AND DISCUSSION. We have presented the current status and the history of physical oceanography in the Angolan territorial waters. Until recently, understanding of the eastern boundary circulation off Angola was derived from a few ship campaigns delivering synoptic geostrophic circulation patterns as well as some time series measurements on the Angolan shelf. The advances of knowledge from these observations were surely limited given the importance of the circulation variability for the highly productive marine ecosystem and associated fisheries (Gammelsrød et al. 1998) as well as for regional and remote climate variability (Rouault et al. 2003).

Within the Nansen Programme executed by the FAO and funded by the Norwegian Agency for Development Cooperation (NORAD), a large number 

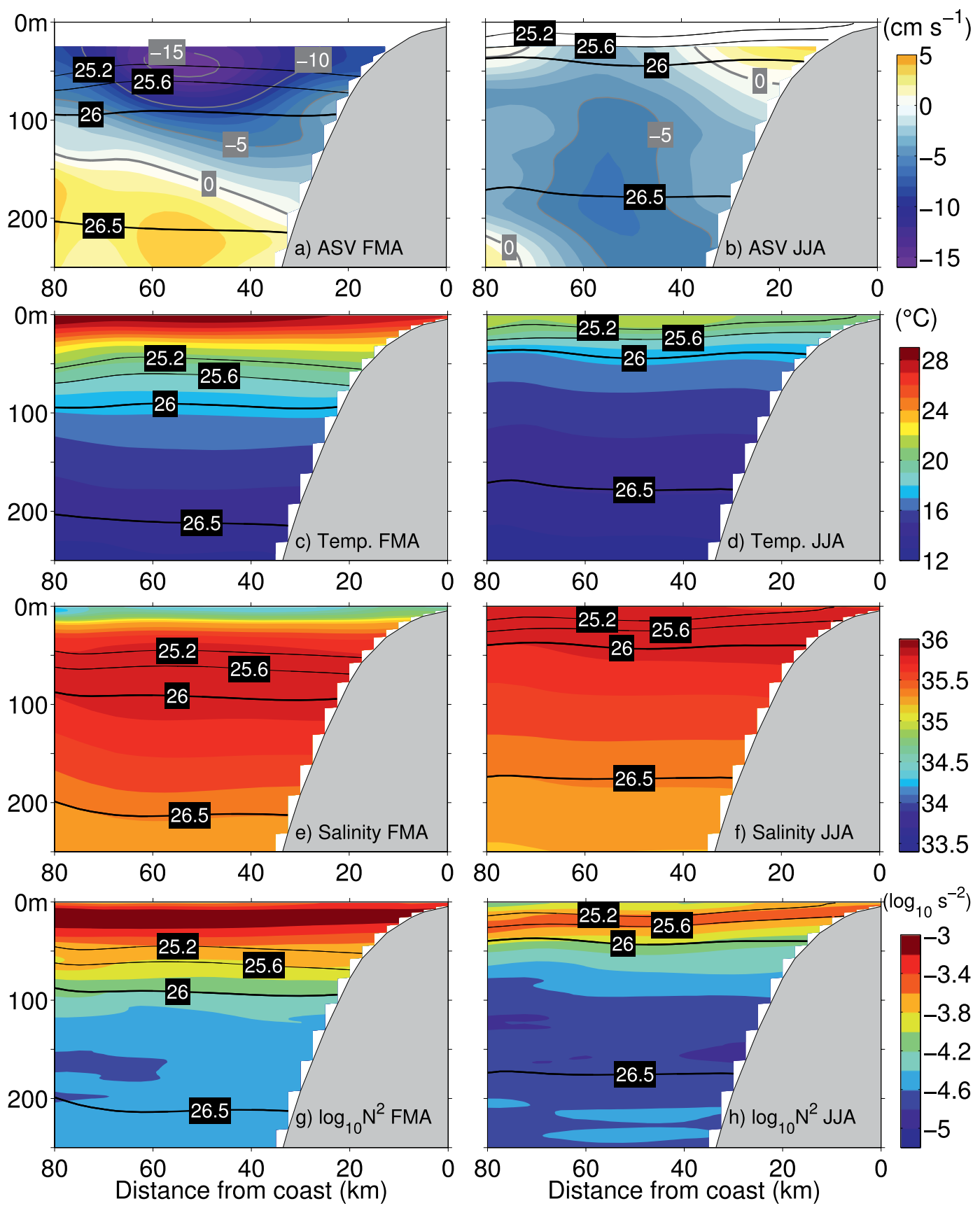

FIG. II. Average sections of (a),(b) alongshore velocity; (c),(d) temperature; (e),(f) salinity; and (g),(h) log , of buoyancy frequency squared for (left) austral summer and (right) austral winter calculated from all available Nansen data between $10^{\circ}$ and $12^{\circ} \mathrm{S}$.

of hydrographic and upper-ocean velocity measurements were acquired during biannual cruises carried out with the R/V Dr. Fridtjof Nansen since 1984. As the result of the joint Angolan and European institutional effort in the frame of the EU-PREFACE project, this extensive time series could be first exploited and shared with the scientific community. To illustrate how this new dataset can be beneficial to the scientific community, also in terms of improving climate model biases and model forecast skills, the salinity data from the Nansen Programme was compared to widely used ocean reanalysis products. As clearly evident in Fig. 14, large biases of up to 0.6 in the mean and seasonal salinity distribution exist in reanalysis products in the upper ocean. It should be noted that biases in the temperature data of the reanalysis products are less pronounced [the reader is referred to Kopte et al. (2017) for details]. The Nansen dataset 
of Angola is now publically available and will lead to improvements of future reanalysis products.

Here, we presented the main aspects emerging from a first analysis of the dataset. The mean alongshore structure of the Angola Current is characterized by a strengthening of the poleward flow between $12^{\circ} \mathrm{S}$ and its maximum just north of the Angola-Benguela Front. This strengthening is presumably driven by the local near-coastal wind stress curl that exhibits a similar increase with latitude. The biannual cruise schedule allows a description of the Angola Current during the main downwelling and upwelling seasons. During the downwelling season in austral summer (February-April), a shallow and pronounced Angola Current is observed, while during the upwelling season in austral winter (June-August) the current is weaker and deeper reaching. The seasonality of the Angola Current is most likely explained by CTWs (Fig. 2). We also noted
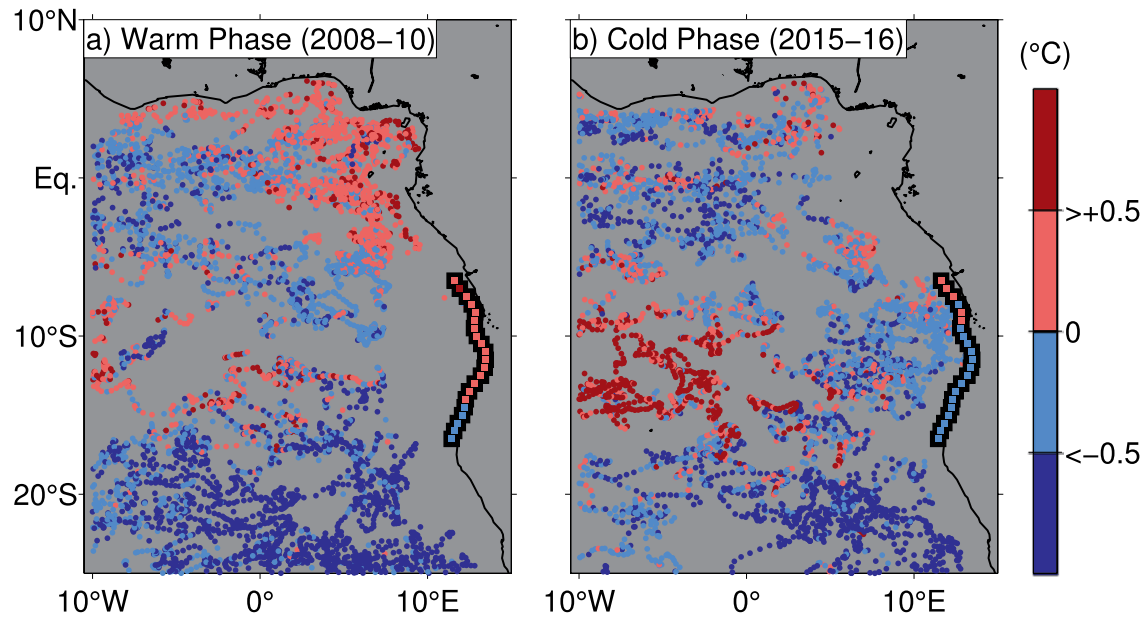

Fig. 13. Subsurface temperature anomalies from Argo profiles (colored dots) and Nansen CTD data (colored squares) for the periods of (a) warm (2008-10) and (b) cold (2015-16) subsurface temperature anomalies off the coast of Angola (cf. Fig. I lb). Temperature was averaged in the density range $26.0 \leq \sigma_{\theta} \leq 26.5 \mathrm{~kg} \mathrm{~m}^{-3}$, and anomalies were derived with respect to a reference temperature corresponding to the total mean of all available Nansen data shown in the latitude-time distribution of Fig. I2b. the good agreement of the Angola Current velocity structure determined from the Nansen shipboard velocity data and from the velocity data from a recently established mooring array at about $11^{\circ} \mathrm{S}$ (Kopte et al. 2017). The somewhat weaker mooring velocities may indicate a period of weaker flow between June 2013 and October 2015, a period during which the thermocline along the Angolan continental margin cooled.

There is a strong seasonality in near-surface temperature and salinity off Angola (Fig. 1). During February-April, the upper ocean off Angola is fresh and warm, while during June-August it is more saline and cold. In this region evaporation exceeds precipitation during the whole year [TropFlux (Praveen Kumar at al. 2012); Global Precipitation Climatology Project (GPCP), version 2.2 (Huffman et al. 2009)], leaving river runoff as the only explanation as a 

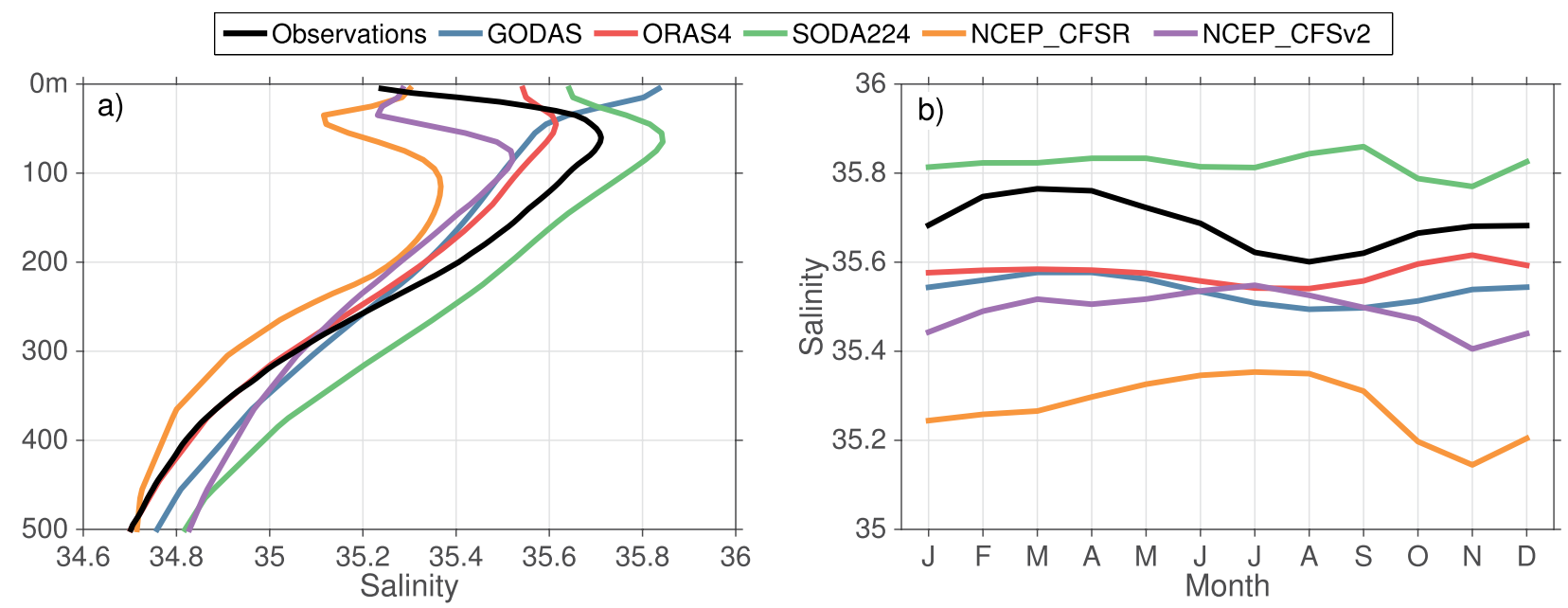

FIG. 14. (a) Mean profiles of salinity from observations (black) and various reanalysis products (colors) derived from individual profiles between $10^{\circ}$ and $11.5^{\circ} \mathrm{S}$ and from $200-$ to $800-\mathrm{m}$ water depth. The observed mean profile is calculated from a mean seasonal salinity distribution, which was derived from all hydrographic observations available in the area between 1968 and 2015 (see Kopte et al. 2017, their Fig. 6c). (b) Corresponding mean seasonal cycles averaged over 50-100-m depth are shown for observations (black) and reanalysis products (colors). Averaging period of the reanalysis salinity values (indicated in the brackets below) varies for the different reanalysis products: Global Ocean Data Assimilation System (GODAS; 1995-2015); Ocean Reanalysis System 4 (ORAS4; 1995-2014); Simple Ocean Data Assimilation (SODA), version 2.2.4 (1995-2010); National Centers for Environmental Prediction (NCEP) Climate Forecast System Reanalysis (CFSR; 1995-2010); and NCEP Climate Forecast System, version 2 (CFSv2; $2011-15)$. A corresponding comparison of temperature is presented in Kopte et al. (2017).

source for the freshwater anomaly in austral summer (Fig. 1c). Moreover, transport by the Congo River, the dominant continental freshwater source in this region, peaks from November to January (Dai et al. 2009). Parts of the Congo River discharge located at $6^{\circ} \mathrm{S}$ must then be carried poleward by the Angola Current during austral summer. In austral autumn, excess evaporation over precipitation then degrades the freshwater anomaly. A secondary but weaker near-surface freshening from November to December was recently described by Kopte et al. (2017) from hydrographic data collected at $11^{\circ} \mathrm{S}$ that confirmed early results gained from time series measurements on the Angolan shelf (Berrit and Dias 1977).

Despite the importance of physical processes for the seasonality of primary productivity and its longterm variability, many gaps in our understanding of the tropical upwelling system of Angola remain. This dataset and previous studies suggest that seasonal upwelling and downwelling off Angola is mostly associated with the propagation of CTWs. However, the forcing of these waves, either remotely from the equator or by winds at the eastern boundary, is not fully understood. Kopte et al. (2018) suggest that the annual cycle is dominantly forced remotely at the equator, while the semiannual cycle is strongly modified either by winds at the eastern boundary or nonlinear interactions of the CTWs with the shelf topography. Furthermore, the impact of these waves on the processes that supply nutrients to the euphotic zone and thus lead to primary productivity remains elusive. As discussed by Ostrowski et al. (2009), the main upwelling season off Angola in austral winter coincides with the seasonal minima of alongshore winds. Upwelling due to Ekman divergence is thus not adequate to explain the primary productivity maximum during this season. Other processes such as internal wave-induced mixing were suggested to contribute to the nutrient supply to the near-surface layers. It is interesting to note the elevated changes of stratification between austral summer and winter in the deeper waters (100-400-m depth; Fig. 10) that were most likely associated with the propagation of CTWs. Stratification controls the transfer of tidally induced internal wave energy onto the shelf (e.g., Hall et al. 2013) that fuels diapycnal nutrient fluxes at the continental margin (e.g., Schafstall et al. 2010). Process studies are needed to resolve these issues in the future.

With the Nansen dataset, we were able to identify strong interannual variability of subsurface upperocean heat content in isopycnal layers. The warm and cold periods that are persisting for several years are most likely due to the variability of Angola Current 
transport. During periods of strong southward flow, warmer and more saline central water masses from the eastern equatorial Atlantic are transported farther to the south, while during periods of weak southward flow, cooler waters originating south of the AngolaBenguela Front may penetrate into the Angolan upwelling system. The potential of the subsurface heat content anomalies for preconditioning of Benguela Niño or Niña events remains an open question.

Another aspect requiring further research is the interannual variability in the near-surface stratification associated with freshwater input due to precipitation and river outflow. Increased near-surface stratification can enhance surface warming because of reduced mixing (possibly even further enhancing the near-surface stratification), but it can also affect the onshore propagation of internal waves and thereby increase mixing and upward nutrient fluxes on the shelf. With sea surface salinity data from satellite remote sensing becoming available during recent years in combination with frequent shipboard observations, it should be possible to address the impact of interannually varying near-surface stratification on the nutrient supply and biological productivity more rigorously.

A better understanding of the processes at work will help to improve numerical simulations of the eastern boundary circulation by reducing the still substantial biases in the velocity structures, stratification, and upwelling strength. It will ultimately improve coupled climate models and thus the prediction of warm and cold events, with potentially tremendous socioeconomic benefit for Angola and particularly its coastal communities. The further development of the capacities in Angola will be pivotal to progress in addressing the impact of climate change and climate variability in a so far generally undersampled region of the World Ocean.

ACKNOWLEDGMENTS. We are grateful to Filomena Vaz Velho for her support in implementing the capacity strengthening program. Also, we would like to acknowledge the three anonymous reviewers for their thoughtful and constructive comments. This study was supported by the German Federal Ministry of Education and Research as part of the SACUS project (03G0837A), and by the European Union 7th Framework Programme (FP7 2007-2013) under Grant Agreement 603521 PREFACE project. Most of the CTD and shipboard ADCP data were acquired within the monitoring component of the Nansen Programme in cooperation with the Instituto Nacional de Investigação Pesqueira (INIP) in Angola and were funded by the Norwegian Agency for Development Cooperation (NORAD).
Datasets described in the "Eastern boundary circulation and hydrography off Angola" and "Interannual variability of hydrography" sections are available through the world data center PANGAEA at https://doi.pangaea.de/I0.1594 /PANGAEA.886492. Microwave OISST data are produced by Remote Sensing Systems and sponsored by the National Oceanographic Partnership Program (NOPP) and the NASA Earth Science Physical Oceanography Program. Data are available online (www.remss.com).

\section{REFERENCES}

Bachèlery, M.-L., S. Illig, and I. Dadou, 2016: Interannual variability in the South-East Atlantic Ocean, focusing on the Benguela Upwelling System: Remote versus local forcing. J. Geophys. Res. Oceans, 121, 284-310, https://doi.org/10.1002/2015JC011168.

Berrit, G. R., and C. A. Dias, 1977: Hydroclimatologie des Régions Côtières de L'Angola. Cahiers O.R.S.T.O.M. Ser. Oceanogr., 15, 181-196.

Bianchi, G., Å. Bjordal, K. A. Koranteng, M. Tandstad, B. Sambe, and T. Stromme, 2016: Collaboration between the Nansen Programme and the Large Marine Ecosystem Programmes. Environ. Dev., 17 (Suppl.), 340-348, https://doi.org/10.1016/j.envdev .2015.11.003.

Bourlès, B., and Coauthors, 2008: The PIRATA program: History, accomplishments and future directions. Bull. Amer. Meteor. Soc., 89, 1111-1125, https:// doi.org/10.1175/2008BAMS2462.1.

Boyer, D. C., and I. Hampton, 2001: An overview of the living marine resources of Namibia. $S$. Afr. J. Mar. Sci., 23, 5-35, https://doi.org/10.2989 /025776101784528953.

Dai, A., T. Qian, K. E. Trenberth, and J. D. Milliman, 2009: Changes in continental freshwater discharge from 1948 to 2004. J. Climate, 22, 2773-2791, https:// doi.org/10.1175/2008JCLI2592.1.

Diakhaté, M., G. de Coëtlogon, A. Lazar, M. Wade, and A. T. Gaye, 2016: Intraseasonal variability of tropical Atlantic sea-surface temperature: Air-sea interaction over upwelling fronts. Quart. J. Roy. Meteor. Soc., 142, 372-386, https://doi.org/10.1002/qj.2657.

Dias, C. A., 1983a: Note on the evidence of a permanent southward flow of the upper oceanic tropospheric waters off Angola at $12^{\circ} \mathrm{S}$. Collection of scientific papers of the International Commission for the Southeast Atlantic Fisheries, No. 10, 99-102.

_- 1983b: Preliminary report on the physical oceanography off southern Angola, March and July 1971. Collection of scientific papers of the International Commission for the Southeast Atlantic Fisheries, No. 10, 103-116. 
FAO, 2011: Fishery and aquaculture country profiles: Republic of Angola, www.fao.org/fishery/facp /AGO/en.

Fennel, W., T. Junker, M. Schmidt, and V. Mohrholz, 2012: Response of the Benguela upwelling systems to spatial variations in the wind stress. Cont. Shelf Res., 45, 65-77, https://doi.org/10.1016/j.csr.2012.06.004.

Florenchie, P., C. J. C. Reason, J. R. E. Lutjeharms, M. Rouault, C. Roy, and S. Masson, 2004: Evolution of interannual warm and cold events in the southeast Atlantic Ocean. J. Climate, 17, 2318-2334, https:// doi.org/10.1175/1520-0442(2004)017<2318:EOIWA C>2.0.CO;2.

Gammelsrød, T., C. H. Bartholomae, D. C. Boyer, V. L. L. Filipe, and M. J. O'Toole, 1998: Intrusion of warm surface water along the Angolan-Namibian coast in February-March 1995: The 1995 Benguela Nino. S. Afr. J. Mar. Sci., 19, 41-56, https://doi.org/10.2989 /025776198784126719.

Goubanova, K., S. Illig, E. Machu, V. Garçon, and B. Dewitte, 2013: SST subseasonal variability in the central Benguela upwelling system as inferred from satellite observations (1999-2009). J. Geophys. Res. Oceans, 118, 4092-4110, https://doi.org/10.1002 /jgrc.20287.

Gruber, N., 2011: Warming up, turning sour, losing breath: Ocean biogeochemistry under global change. Philos. Trans. Roy. Soc. London, A369, 1980-1996, https://doi .org/10.1098/rsta.2011.0003.

Hall, R. A., J. M. Huthnance, and R. G. Williams, 2013: Internal wave reflection on shelf slopes with depthvarying stratification. J. Phys. Oceanogr., 43, 248-258, https://doi.org/10.1175/JPO-D-11-0192.1.

Huffman, G. J., R. F. Adler, D. T. Bolvin, and G. Gu, 2009: Improving the global precipitation record: GPCP version 2.1. Geophys. Res. Lett., 36, L17808, https://doi.org/10.1029/2009GL040000.

Imbol Koungue, R. A., S. Illig, and M. Rouault, 2017: Role of interannual Kelvin wave propagations in the equatorial Atlantic on the Angola Benguela current system. J. Geophys. Res. Oceans, 122, 4685-4703, https://doi.org/10.1002/2016JC012463.

Jarre, A., and Coauthors, 2015: Synthesis: Climate effects on biodiversity, abundance and distribution of marine organisms in the Benguela. Fish. Oceanogr., 24, 122-149, https://doi.org/10.1111/fog.12086.

Junker, T., M. Schmidt, and V. Mohrholz, 2015: The relation of wind stress curl and meridional transport in the Benguela upwelling system. J. Mar. Syst., 143, 1-6, https://doi.org/10.1016/j.jmarsys.2014.10.006.

—, V. Mohrholz, L. Siegfried, and A. van der Plas, 2017: Seasonal to interannual variability of water mass characteristics and currents on the Namibian shelf. J. Mar. Syst., 165, 36-46, https://doi.org/10.1016/j .jmarsys.2016.09.003.

Kopte, R., P. Brandt, M. Dengler, P. C. M. Tchipalanga, M. Macuéria, and M. Ostrowski, 2017: The Angola Current: Flow and hydrographic characteristics as observed at $11^{\circ} \mathrm{S}$. J. Geophys. Res. Oceans, 122, 1177-1189, https://doi.org/10.1002/2016JC012374.

—, - M. Claus, R. J. Greatbatch, and M. Dengler, 2018: Role of basin-mode resonance for the seasonal variability of the Angola Current. J. Phys. Oceanogr., 48, 261-281, https://doi.org/10.1175/JPO-D-17-0111.1. Koseki, S., N. Keenlyside, T. Demissie, T. Toniazzo, F. Counillon, I. Bethke, M. Ilicak, and M.-L. Shen, 2018: Causes of the large warm bias in the AngolaBenguela Frontal Zone in the Norwegian Earth System Model. Climate Dyn., 50, 4651-4670, https:// doi.org/10.1007/s00382-017-3896-2.

Kostianoy, A. G., and J. R. E. Lutjeharms, 1999: Atmospheric effects in the Angola-Benguela frontal zone. J. Geophys. Res., 104, $20963-20$ 970, https://doi .org/10.1029/1999JC900017.

Lamb, K., 2014: Internal wave breaking and dissipation mechanisms on the continental slope/shelf. Annu. Rev. Fluid Mech., 46, 231-254, https://doi .org/10.1146/annurev-fluid-011212-140701.

Lass, H. U., M. Schmidt, V. Mohrholz, and G. Nausch, 2000: Hydrographic and current measurements in the area of the Angola-Benguela Front. J. Phys. Oceanogr., 30, 2589-2609, https://doi.org/10.1175/1520 -0485(2000)030<2589:HACMIT>2.0.CO;2.

Lazar, A., I. Polo, S. Arnault, and G. Mainsant, 2006: Kelvin waves activity in the eastern Tropical Atlantic. Proc. Symp. on 15 Years of Progress in Radar Altimetry, ESA SP-614, Venice, Italy, ESA, http://earth.esa.int /cgi-bin/confalt15y0aeb.html?abstract=1263.

Lehodey, P., and Coauthors, 2006: Climate variability, fish, and fisheries. J. Climate, 19, 5009-5030, https:// doi.org/10.1175/JCLI3898.1.

Lübbecke, J. F., C. W. Böning, N. S. Keenlyside, and S.-P. Xie, 2010: On the connection between Benguela and equatorial Atlantic Niños and the role of the South Atlantic Anticyclone. J. Geophys. Res., 115, C09015, https://doi.org/10.1029/2009JC005964.

Lutjeharms, J. R. E., and J. M. Meeuwis, 1987: The extent and variability of South-East Atlantic upwelling. $S$. Afr. J. Mar. Sci., 5, 51-62.

Marchesiello, P., J. C. McWilliams, and A. Shchepetkin, 2003: Equilibrium structure and dynamics of the California Current System. J. Phys. Oceanogr., 33, 753-783, https://doi.org/10.1175/1520-0485(2003)33 $<753$ :ESADOT>2.0.CO;2.

McCreary, J. P., Jr., and S.-Y. Chao, 1985: Three-dimensional shelf circulation along an eastern ocean 
boundary. J. Mar. Res., 43, 13-36, https://doi.org/10.1357 /002224085788437316.

Meeuwis, J. M., and J. R. E. Lutjeharms, 1990: Surface thermal characteristics of the Angola-Benguela front. S. Afr. J. Mar. Sci., 9, 261-279, https://doi.org $/ 10.2989 / 025776190784378772$.

Mercier, H., M. Arhan, and J. R. E. Lutjeharms, 2003: Upper-layer circulation in the eastern Equatorial and South Atlantic Ocean in January-March 1995. Deep-Sea Res. I, 50, 863-887, https://doi.org/10.1016 /S0967-0637(03)00071-2.

Mohrholz, V., M. Schmidt, and J. R. E. Lutjeharms, 2001: The hydrography and dynamics of the AngolaBenguela Frontal Zone and environment in April 1999. S. Afr. J. Sci., 97, 199-208.

_ C. H. Bartholomae, A. K. van der Plas, and H. U. Lass, 2008: The seasonal variability of the northern Benguela undercurrent and its relation to the oxygen budget on the shelf. Cont. Shelf Res., 28, 424-441, https://doi.org/10.1016/j.csr.2007.10.001.

Monteiro, P. M. S., A. K. van der Plas, J. L. Mélice, and P. Florenchie, 2008: Interannual hypoxia variability in a coastal upwelling system: Ocean-shelf exchange, climate and ecosystem-state implications. Deep-Sea Res. I, 55, 435-450, https://doi.org/10.1016/j.dsr.2007.12.010.

- B. Dewitte, M. I. Scranton, A. Paulmier and A. K van der Plas, 2011: The role of open ocean boundary forcing on seasonal to decadal-scale variability and long-term change of natural shelf hypoxia. Environ. Res. Lett., 6, 025002, https://doi.org/10.1088/1748 $-9326 / 6 / 2 / 025002$.

Moroshkin, K. V., V. A. Bunov, and R. P. Bulatov, 1970: Water circulation in the eastern South Atlantic Ocean. Oceanology, 10, 27-34.

Nicholson, S. E., 2010: A low-level jet along the Benguela Coast, an integral part of the Benguela current ecosystem. Climatic Change, 99, 613-624, https://doi .org/10.1007/s10584-009-9678-z.

Ostrowski, M., 2007: Impact of equatorial Kelvin waves on aggregation of sardinellas (Sardinella spp.) in Angolan waters. ICES Doc. CM 2007/G:08, 32 pp., www.ices.dk/sites/pub/CM\%20Doccuments/CM -2007/G/G0807.pdf.

_ - J. C. B. da Silva, and B. Bazik-Sangolay, 2009: The response of sound scatterers to El Niño- and La Niña-like oceanographic regimes in the southeastern Atlantic. ICES J. Mar. Sci., 66, 1063-1072, https:// doi.org/10.1093/icesjms/fsp102.

Parrish, R. H., F. B. Schwing, and R. Mendelssohn, 2000: Mid-latitude wind stress: the energy source for climatic shifts in the North Pacific Ocean. Fish. Oceanogr., 9, 224-238, https://doi.org/10.1046/j.1365 $-2419.2000 .00136 . x$.
Patricola, M. C., and P. Chang, 2017: Structure and dynamics of the Benguela low-level coastal jet. Climate Dyn., 49, 2765-2788, https://doi.org/10.1007/ s00382-016-3479-7.

Peterson, R. G., and L. Stramma, 1991: Upper-level circulation in the South Atlantic Ocean. Prog. Oceanogr., 26, 1-73, https://doi.org/10.1016/00796611(91)90006-8.

Poole, R., and M. Tomczak, 1999: Optimum multiparameter analysis of the water mass structure in the Atlantic Ocean thermocline. Deep-Sea Res. I, 46, 1895-1921, https://doi.org/10.1016/S0967-0637(99) 00025-4.

Praveen Kumar, B. P., J. Vialard, M. Lengaigne, V. S. N. Murty, and M. J. McPhaden, 2012: TropFlux: Airsea fluxes for the global tropical oceans-Description and evaluation. Climate Dyn., 38, 1521-1543, https://doi.org/10.1007/s00382-011-1115-0.

Risien, C. M., and D. B. Chelton, 2008: A global climatology of surface wind and wind stress fields from eight years of QuikSCAT scatterometer data. J. Phys. Oceanogr., 38, 2379-2413, https://doi .org/10.1175/2008JPO3881.1.

Rouault, M., 2012: Bi-annual intrusion of tropical water in the northern Benguela upwelling. Geophys. Res. Lett., 39, L12606, https://doi.org/10.1029/2012GL052099.

- P. Florenchie, N. Fauchereau, and C. J. C. Reason, 2003: South East tropical Atlantic warm events and southern African rainfall. Geophys. Res. Lett., 30, 8009, https://doi.org/10.1029/2002GL014840.

—, S. Illig, C. Bartholomae, C. J. C. Reason, and A. Bentamy, 2007: Propagation and origin of warm anomalies in the Angola Benguela upwelling system in 2001. J. Mar. Syst., 68, 473-488, https://doi .org/10.1016/j.jmarsys.2006.11.010.

,-- J J. Lübbecke, and R. A. I. Koungue, 2018: Origin, development and demise of the 2010-2011 Benguela Niño. J. Mar. Syst., https://doi.org/10.1016/j .jmarsys.2017.07.007, in press.

Sætelsdal, G., G. Bianchi, and T. Strømme, 1999: The Dr. Fridtjof Nansen Programme 1975-1993: Investigations of fishery resources in developing regions: History of the programme and review of results. FAO Fisheries Tech. Paper 391, 434 pp.

Schafstall, J., M. Dengler, P. Brandt, and H. Bange, 2010: Tidal-induced mixing and diapycnal nutrient fluxes in the Mauritanian upwelling region. J. Geophys. Res., 115, C10014, https:/doi .org/10.1029/2009JC005940.

Schmidtko, S., L. Stramma, and M. Visbeck, 2017: Decline in global oceanic oxygen content during the past five decades. Nature, 542, 335-339, https://doi .org/10.1038/nature21399. 
Schouten, M. W., R. P. Matano, and T. P. Strub, 2005: A description of the seasonal cycle of the equatorial Atlantic from altimeter data. Deep-Sea Res. I, 52, 477-493, https://doi.org/10.1016/j.dsr.2004.10.007.

Shannon, L. V., A. J. Boyd, G. B. Brundrit, and J. Taunton-Clark, 1986: On the existence of an El Niño-type phenomenon in the Benguela System. J. Mar. Res., 44, 495-520, https://doi.org/10.1357 /002224086788403105.

— J. J. Agenbag, and M. E. L. Buys, 1987: Largeand mesoscale features of the Angola-Benguela front. S. Afr. J. Mar. Sci., 5, 11-34, https://doi.org /10.2989/025776187784522261.

Small, R. J., E. Curchitser, K. Hedstrom, B. Kauffman, and W. G. Large, 2015: The Benguela upwelling system: Quantifying the sensitivity to resolution and coastal wind representation in a global climate model. J. Climate, 28, 9409-9432, https://doi.org /10.1175/JCLI-D-15-0192.1.

Stramma, L., G. C. Johnson, J. Sprintall, and V. Mohrholz, 2008: Expanding oxygen-minimum zones in the tropical oceans. Science, 320, 655-658, https://doi .org/10.1126/science.1153847.

Toniazzo, T., and S. Woolnough, 2014: Development of warm SST errors in the southern tropical Atlantic in CMIP5 decadal hindcasts. Climate Dyn., 43,
2889-2913, https://doi.org/10.1007/s00382-013$1691-2$.

Wacongne, S., and B. Piton, 1992: The near-surface circulation in the northeastern corner of the South Atlantic ocean. Deep-Sea Res., 39A, 1273-1298, https://doi.org/10.1016/0198-0149(92)90069-6.

Wahl, S., M. Latif, W. Park, and N. Keenlyside, 2011: On the tropical Atlantic SST warm bias in the Kiel Climate Model. Climate Dyn., 36, 891-906, https:// doi.org/10.1007/s00382-009-0690-9.

Wattenberg, H., 1938: Die Verteilung des Sauerstoffs im Atlantischen Ozean. De Gruyter, 132 pp.

Wüst, G., 1935: Die Stratosphäre des Atlantischen Ozeans. De Gruyter, 288 pp.

Xu, Z., M. Li, C. M. Patricola, and P. Chang, 2014: Oceanic origin of southeast tropical Atlantic biases. Climate Dyn., 43, 2915-2930, https://doi.org/10.1007 /s00382-013-1901-y.

Zuidema, P., and Coauthors, 2016: Challenges and prospects for reducing coupled climate model SST biases in the eastern tropical Atlantic and Pacific Oceans: The U.S. CLIVAR Eastern Tropical Oceans Synthesis Working Group. Bull. Amer. Meteor. Soc., 97, 2305-2328, https://doi.org/10.1175/BAMS-D-15 -00274.1 . 
Find out from the authoritative source th

\section{[ What's a dust devil? ]}

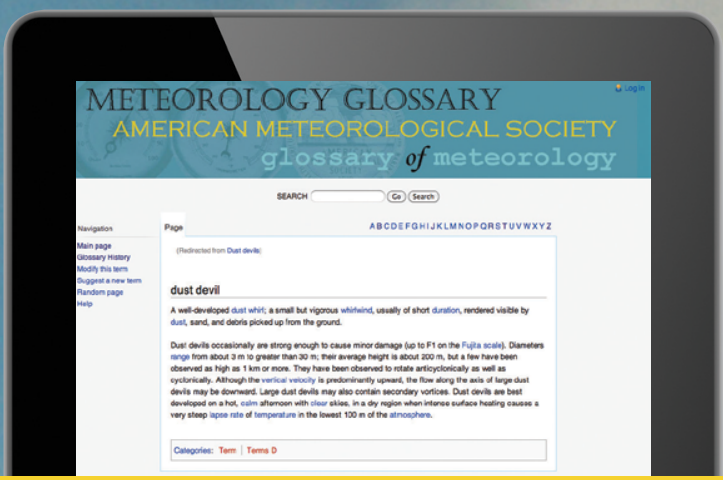

THE A MER ICA N METEOROLOG I CAL S O I I T Y

\section{Online Glossary of Meteorology}

With over 12,000 meteorological terms, you'll be able to look up definitions online any time, any place, anywhere. http://glossary.ametsoc.org/wiki

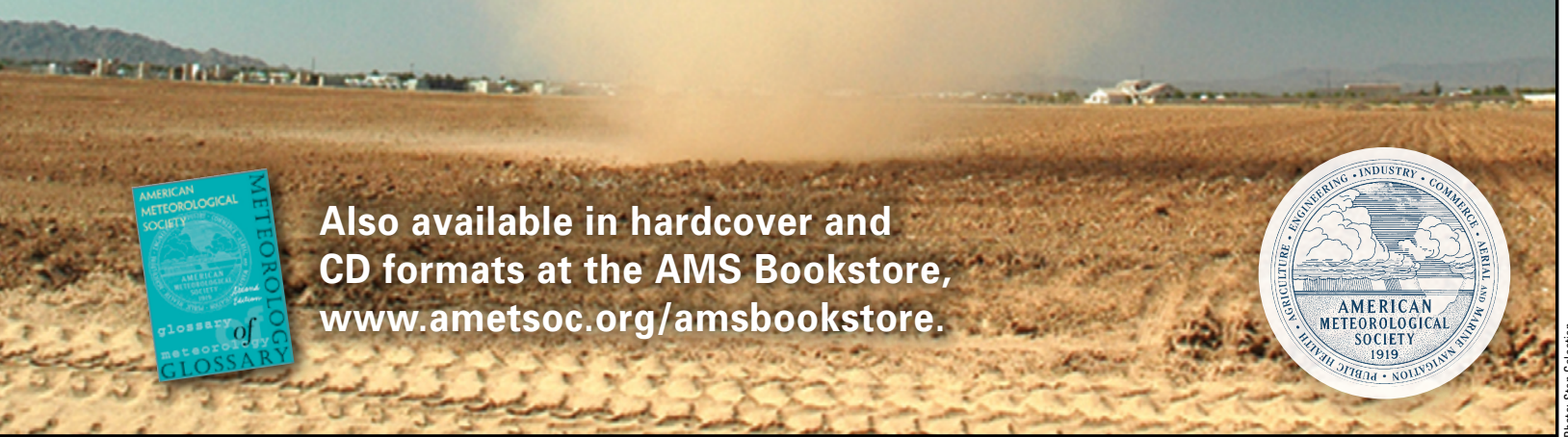

